\title{
MECHANIZED RECLAMATION OF SWAMPLANDS IN FINLAND
}

\author{
Kauko Maijala \\ Pellonraivaus Oy, Helsinki
}

Received December 1, 1955.

During the present century Finnish agriculture has been characterized by vigorous land clearing operations. The total area of cultivated land in Finland in 1900 was 1568072 ha., thereafter the amount of land cleared at different periods has been as follows (2):

Period
$1900-1920$
$1921-1939$
$1940-1944$
$1945-1954$

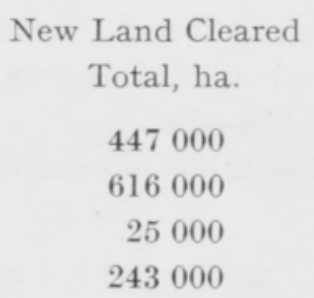

In the last war, Finland lost altogether about 287000 ha. of cultivated land (2). In order to make up for this loss, the Finns proceeded during the years 19451954 to clear approximately 243000 ha. of new land, as indicated in the above table. Thus, the total area of cultivated land in Finland is at present still somewhat smaller than in 1939.

The population of Finland on January 1st, 1953, was about 4165000 , and the area of cultivated land per capita 0.60 ha. (6). According to an estimate made in 1949, the population will grow to about 4406000 by 1970 , about 4735000 by 1990 , and to about 4863000 in the year 2000 (1). As, on the other hand, it is estimated that the maintenance of self-sufficiency in respect to agricultural produce would require a cultivated area of approximately 0.75 ha. per capita (3), continued land clearance operations are essential, if only to raise the degree of self-sufficiency to a satisfactory level. If, in addition, it is desired to expand the productive land area in ratio to the growth in population, there would have to be about 3200000 ha. of cultivated land in Finland by 1975 , which means that up to that year roughly 600000 ha. of new land would have to be brought under the plough. 


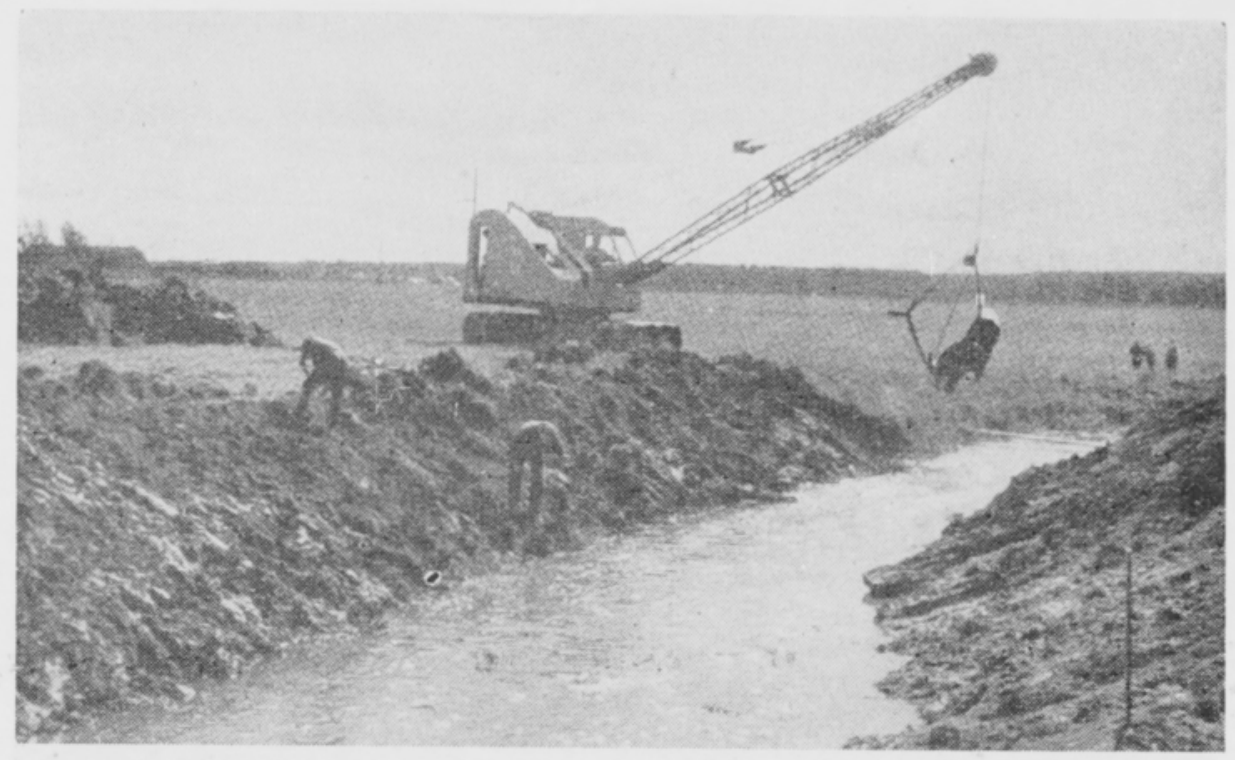

Fig. 1. A Link-Belt dragline equipped with a $0.4 \mathrm{~m}^{3}$ bucket engaged in clearing out a discharge drain.

According to recently made conservative estimates, Finland has approximately $1614000 \mathrm{ha}$. of land capable of being reclaimed. Of this total the northern part of the country, consisting of the provinces of Oulu and Lapland, accounts for 1276100 ha. and the southern part for 337400 ha. (3). The main part of the reclaimable area consists of swampland (i.e. wet peatland), which forms about $65 \%$ of the above figure for southern Finland and about $90 \%$ for northern Finland. The average share of swampland in relation to the total reclaimable area is approximately $85 \%$. The main emphasis in the reclamation program will therefore continue to be placed on the reclaiming of swamps.

The following is a report on the experiences gained in Finland during the past ten years in the reclamation of swamplands and on the mechanical methods used in the work.

\section{Drainage Operations}

In a drainage project the first task is the levelling of the surface of the reclaimable swamp and the determining of the thickness of the peat layer and the quality of the subsoil. In drainage the peat loses a considerable part of its water content and this, in turn, causes a sinking of the surface, which reduces the thickness of the peat layer, depending on its quality, by between 10 and $40 \%$. This shrinkage must especially be taken into account, together with the slope of the substratum, in the planning of any system of discharge drains, to ensure that these drains will be at the lowest points even after the sinking has taken place, and that their slope remains as planned. The surface of a swamp continues to sink each year as a result of tillage from 0.5 to $1.5 \mathrm{~cm}$., and this factor must likewise be taken into account in planning drainage operations. 


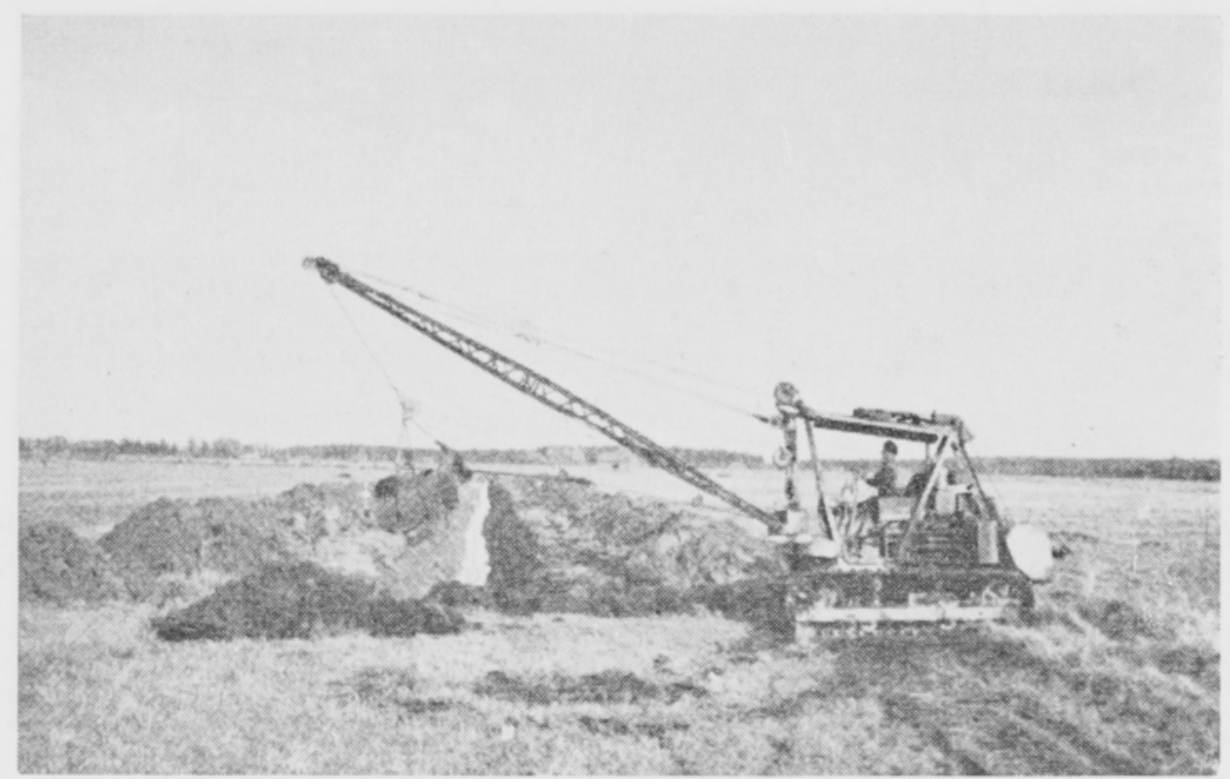

Fig. 2. A dragline attached to a Caterpillar $\mathrm{D}_{4}$ tractor at work. Capacity of bucket: $0.2 \mathrm{~m}^{3}$.

In the digging of discharge drains, excavators (Fig. 1.) have been used as far as possible. In the conditions in which work generally has to be done on wet peatlands, a dragline equipped with a $0.3-0.4 \mathrm{~m}^{3}$. bucket has proved to be the most effective machine provided that the surface width of the drain is less than $6-7 \mathrm{~m}$. and the volume of earth dug is $3-5 \mathrm{~m}^{3} . / \mathrm{rm}$. With such an excavator the results achieved amount to approximately $30-40 \mathrm{~m}^{3}$ per effective working hour when the swamp is treeless. If there is an abundance of snags and stumps, the results are likely to be only a half of the figures cited. The proportion of effective work is about $70 \%$ of the total work time. In the event that the carrying capacity of the swamp is so limited that platforms must be constructed under the excavator, the results are reduced by about $20 \%$, provided the volume of earth dug is $3-5 \mathrm{~m}^{3} / \mathrm{rm}$. If the clearing out of an old discharge drain or the digging of small boundary ditches is involved, with the volume of earth dug being only $2-3 \mathrm{~m}^{3} . / \mathrm{rm}$., the use of platforms is liable to cause a reduction of as much as $40 \%$ in the work output.

In the digging of small discharge drains it is also possible to use excavators (Fig. 2).

If the digging of feeder drains is done by hand, the work can generally be undertaken immediately after the discharge drains are dug. If, again, open ditches are dug by machine and the carrying capacity of the peat is small, it is most often necessary to dig trap ditches and narrow preparatory ditches at intervals of between 40 and 100 meters before it is possible to set about digging open ditches by machine. The trap ditches and narrow preparatory ditches should be dug in such a case a year or two before the feeder drains are dug.

The most effective machines for digging open ditches in wet peatlands have proved to be the heavy open ditch ploughs designed expressly for draining operations in forests (Fig. 3). These ploughs are capable of giving satisfaction even in swamps 


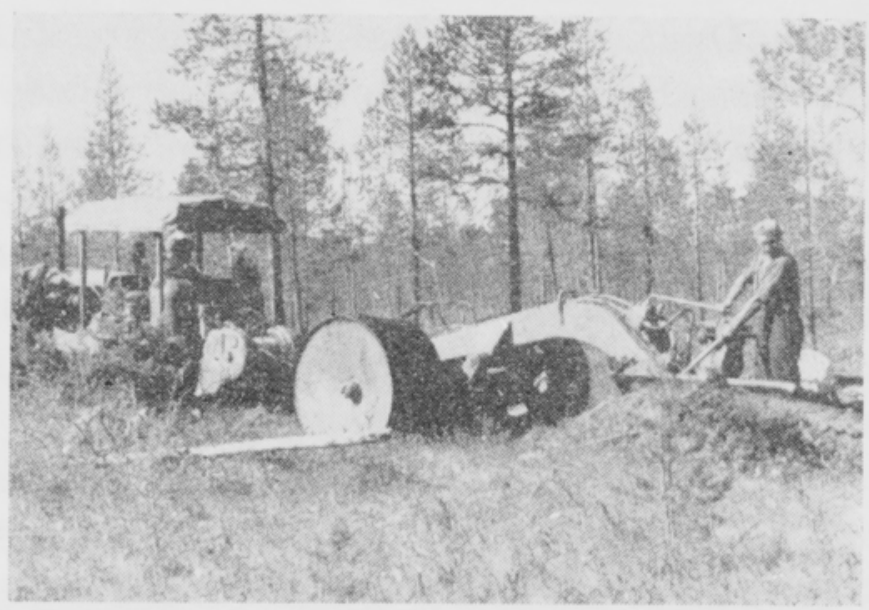

Fig. 3. Forest ditch plow constructed by the Pellonraivaus Oy.

heavily overgrown with trees, where ditching by manual labour has previously involved great difficulties. The amount of work accomplished varies considerably, depending on the local conditions; but the average result for an 8-hour day has been $800-1000$ running meters. Tractors in the Caterpillar $\mathrm{D}_{6}$ and Allis-Chalmers $\mathrm{HD}_{9}$ class fitted with a winch are used as draught machines. In wet peatlands lacking a firm surface it is necessary to increase the carrying capacity of the tractor tracks by adding wide wooden shoes bolted on tracks - a measure that, however, raises the ditching costs to some degree. The machine labour operating costs have been $30-35$ Fmks./rm. Since, in addition, it has been necessary to resort to manual labour in digging the ends of the drains, and, particularly, in cleaning out the ditches in wooded areas, extra costs are involved, amounting on an average to about $10 \mathrm{Fmks} . / \mathrm{rm}$.

In areas of mineral soil and shallow layers of peat turning into swamp, as well as in swamps with thick layers of peat but few snags and stumps, it is possible in the digging of open ditches to use also strongly built open ditch plows designed for reclamation work in ordinary mineral soil, such as e.g. the Liitso-model ploughs

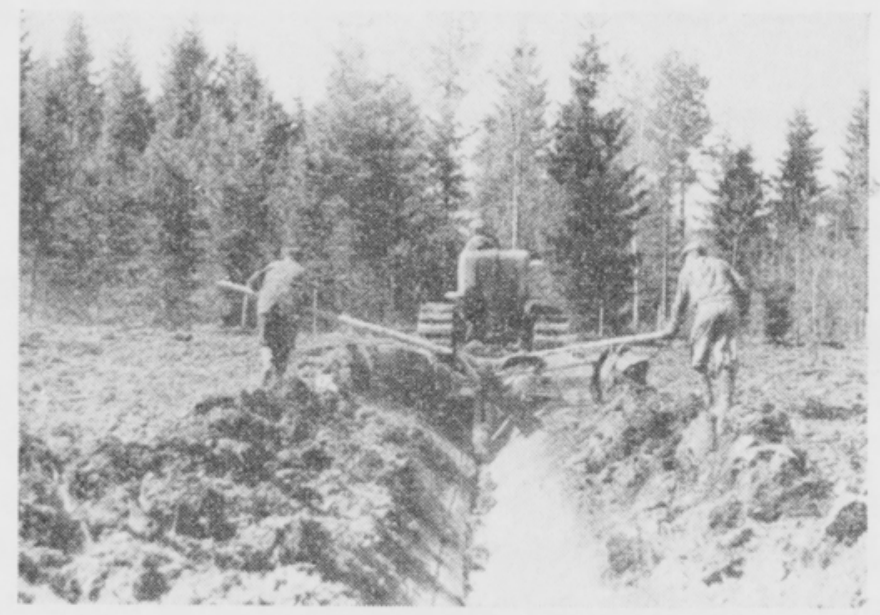

Fig. 4. Land clearing ditching in mineral soil with a Liitso-model plow. Allis-Chalmers $\mathrm{HD}_{5}$-model track-type tractor used as draught machine. 
built by the Pellonraivaus Oy (Fig. 4). The tractors used are of the size of the Caterpillar $\mathrm{D}_{4}$ and Allis-Chalmers $\mathrm{HD}_{5}$. During operations in 1950-1954 (*), a total of approximately $2600 \mathrm{~km}$. were reclaimed. The average expenditure of labour, using the aforesaid ploughs and draught machines, was 3.5 effective working hours per $\mathrm{km}$. of ditch, while the work costs averaged $10.40 \mathrm{Fmk}$. a running meter. In 1954 the corresponding costs were $11.38 \mathrm{Fmk}$. a running meter. The ditches are, however, somewhat smaller than those dug with a forest ditch plough. In such cases, too, the ends of a ditch must be opened by hand labour.

In generally it may be affirmed that digging open ditches by hand should be resorted to only when it is not possible to mechanize operations, as even under favourable conditions the cost of hand labour is as high as $40-50 \mathrm{Fmk} . / \mathrm{rm}$. and in swamps grown over with trees substantially higher.

\section{Clearing and Burning of Small Stands of Trees}

In wet swamps with thick layers of peat the stands of trees are generally small and sparse as well as, most often, shrubby. If the stands, on the other hand, happen to be regular and abundant, their special clearance is necessary. The work involves the cutting, piling and burning of shoots. If there are few trees, piling and burning may be dispensed with, as clearance plowing can be performed without difficulty. For the work output it would be most advantageous to burn the shoots without piling; however, care should be taken not to burn the humus layer on top of the swamp. This danger is lessened by kurring in piles.

The expenditure of labour in cutting down sprouts and burning them varies very much, depending on the conditions. According to work studies, the average expenditure of labour in removing and piling sprouts has been approximately 40 man-hours per ha. (5). The expenditure of labour depends considerably on the denseness of the thickets of sprouts, as can be seen from the following data:

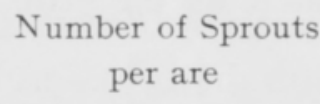

100

200

300

400
Expenditure of Labour Man-hours/ha.

25

45

65

75

The labour costs vary according to the expenditure of labour between 3000 and $10000 \mathrm{Fmk}$./ha., the average being $6500 \mathrm{Fmk}$./ha.

\section{Removal of Stumps}

In swamps with thick layers of peat, stumps generally present no special problem, inasmuch as such areas seldom have stands of trees of such thickness that their

* These and the subsequent statistical data relate to operations carried out by the Pellonraivaus Oy. 
stumps would be an obstruction to clearance operations. In swamps with thin layers of peat and in areas of mineral soil turning to swamp, however, stumps often have to be removed, and this operation generally involves two stages of mechanized labour.

Tearing stumps loose is carried out in mineral soil with machines of the Caterpillar $D_{6}$ and $D_{7}$ class, equipped with a rake blade bulldozer, and these machines represent the standard model for such work. In swamplands with a weak carrying capacity, however, the use of such machines leads to difficulties because they often

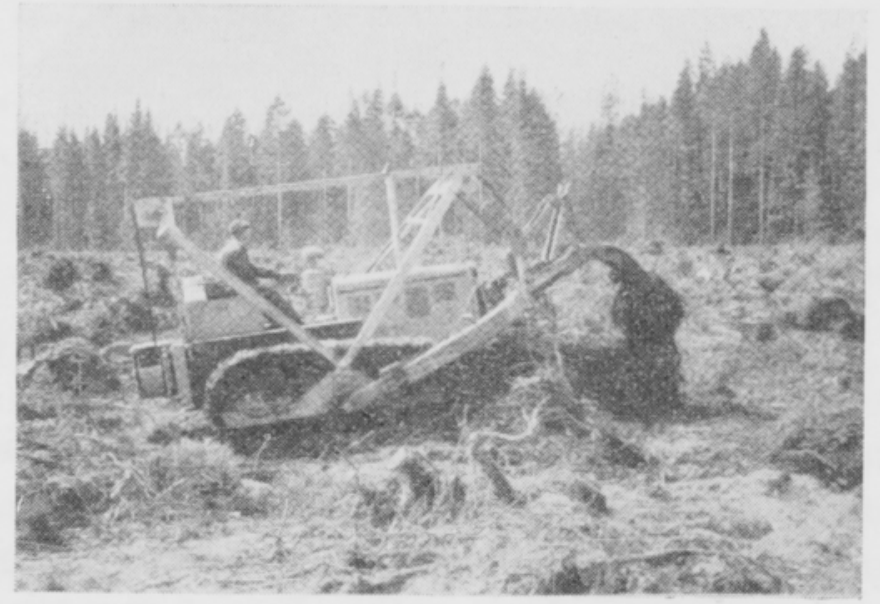

Fig. 5. Caterpillar $\mathrm{D}_{4}$ tractor equipped with a stumpfork for removing stumps.

sink into the mire and because the transportation of the machines is expensive and cumbersome when the small supplementary pieces of land typical of Finland's current clearing activity are involved. In the removal of stumps light caterpillar-type tractors equipped with "stumpforks" (two-prong stumper) are being icnreasingly used. The stumpfork, a double pronged mechanically controlled stumper, is attached to the front of the tractor (Fig. 5). Caterpillar $\mathrm{D}_{4}$-type tractors provide the machine power. Stumpfork machines have proved more advantageous than bulldozers in clearing swamplands for the following reasons, in particular:

1. A stumpfork machine is lighter than an ordinary bulldozer, and it can be transported from one work site to another with an ordinary heavy truck, whereas the transportation of a bulldozer generally requires a special transport car:

2. By virtue of its manner of operation and its light weight, the stumpfork is able to function in softer terrain than the bulldozer and, even so, it bogs down less often.

3. Since lift and pull take place simultaneously in the operation of a stumpfork, the stumps rise up cleaner than when a bulldozer is used, so that usually no separate earth removing operation is needed.

4. Since stumpforks are attached to typical draught machines, it is possible to carry out also clearance plowing, harrowing and ditching with these machines 
on the same work site, which obviates employing different machines on the same project. As also a bulldozer blade can be attached to the beam structure of the stumpfork, the same machine is suited e.g. for light earth moving operations, snow plowing and spreading out the soil dug from ditches.

According to statistics, covering the removal of stumps during the years 1950 - 1954, with bulldozers accounting for approximately 137000 effective working hours and stumpforks for 47000 , the labour expenditure and machine labour costs amounted on an average to the following figures:

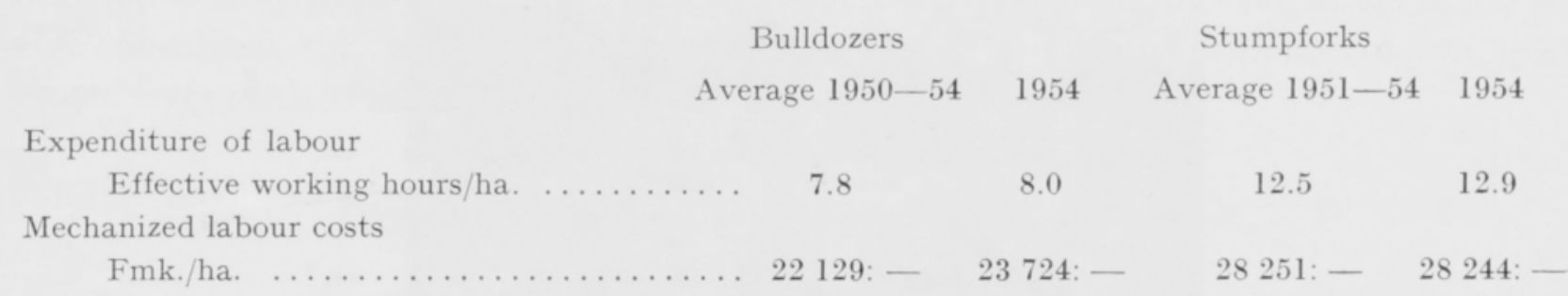

In the treatment of stumps the second mechanized stage is the earth removal. operation. Its purpose is to shake off the earth clinging to the stump when it is forced out of the ground. As pointed out above, such an operation is not generally necessary when stumpforks are used, since the stumps immediately rise up free of clinging earth. In removing stumps with bulldozers, however, it is usually needed. As the earth clinging to the stumps much more easily drops off, owing to the effects of frost, when the earth removal operation is performed the summer after the removal, this procedure is generally to be recommended.

In connection with the earth removal operation, the piling of stumps for burning can also be carried out. In small fields the stumps are generally shoved away from the area altogether. If, on the other hand, large areas to be cleared are involved, the stumps are piled up and burned on the spot.

The clearing away of rocks can be combined with the earth removal operations when there is not a great abundance of rocks in the area.

In certain cases even the cleansing of stumps can be performed with a stumpfork, although only a few such operations have been done so far.

According to statistics for 1950-1954 concerning the cleansing of stumps for a total of about 26000 effective working hours, the average expenditure of labour was 5.2 effective working hours/ha., and the average cost for mechanized operations about $12700 \mathrm{Fmk}$./ha. The corresponding figures for 1954 are 5.3 effective working hours/ha., and $14200 \mathrm{Fmk}$./ha.

\section{Reclamation and Land Clearance ploughing}

In areas of mineral soil reclamation ploughing can generally be carried out only after the burning of the stumps. In wet peatlands, however, when there are no large stumps, ploughing is performed immediately after the thickets have been cut away. 


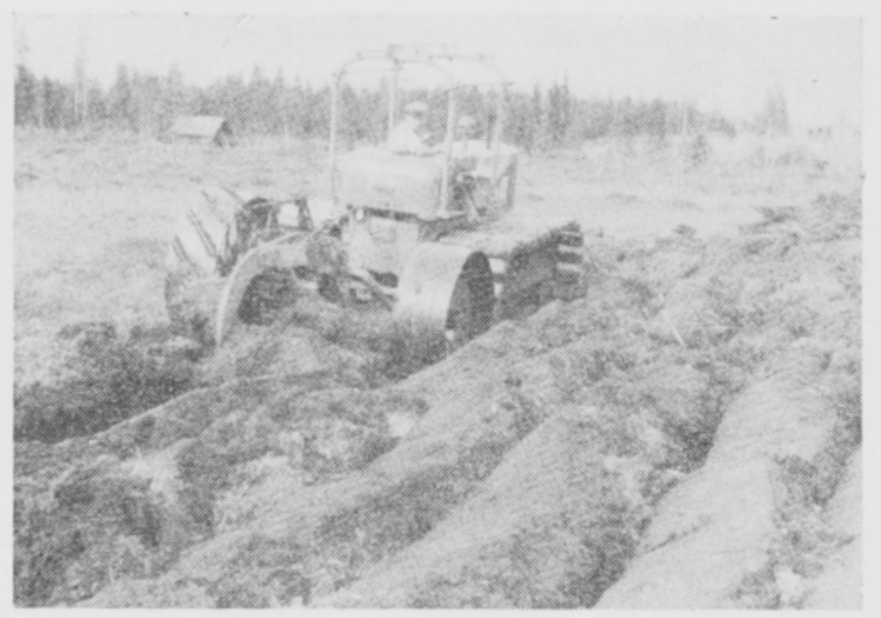

Fig. 6. Land clearing in a bog with a thick layer of peat. Allis-Chalmers $\mathrm{HD}_{5}$ track-type tractor equipped with wooden shoes bolted on tracks. A large Fiskars-model land clearing plow used for plowing.

As five-ton caterpillar-type tractors and heavy-duty specially constructed land clearing ploughs are generally used as draught machines, stumps less than $15 \mathrm{~cm}$. in thickness ordinarily constitute no obstruction to ploughing (Fig. 6). This kind of pioneer ploughing of wet peatland, which has been preceded by no removal of stumps, is accordingly termed land clearance ploughing.

The greatest difficulty in the ploughing of wet peatlands is their low carrying capacity and the consequent bogging down of power machinery, which is especially common when there has not been sufficient basic drainage. In order to prevent sinking, the draught machines are provided with wide wooden track shoes bolted on tracks. As the durability of such shoes is small, particularly when operating in stumpfilled areas, and as attaching them involves considerable extra work, their use adds to the ploughing costs to the extent of $1500-2000 \mathrm{Fmk}$./ ha.

Operations carried out in the years 1950-1954 comprise altogether about 97000 effective working hours of reclamation ploughing, and the expenditure of labour comes to an average of 9.3 effective hours per ha. The average mechanized labour costs reach the figure of about $17600 \mathrm{Fmk}$./ha. The corresponding figures for the year 1954 are 10.4 effective working hours/ha. and about $18900 \mathrm{Fmk}$./ha.

\section{Reclamation Harrowing}

In the process of preparing new land for sowing, reclamation harrowing constitutes the final stage of the mechanized operations. If in connection with the ploughing many stumps and snags have risen to the surface, they must be cleared away before the reclamation harrowing, so as not to become mixed in with the earth and remain a continuous obstruction to tillage. Reclamation harrowing can under favourable conditions be carried out also with wheel tractors and ordinary tilling equipment, in general, however, the unevenness and wetness of the ground prevent their use. 


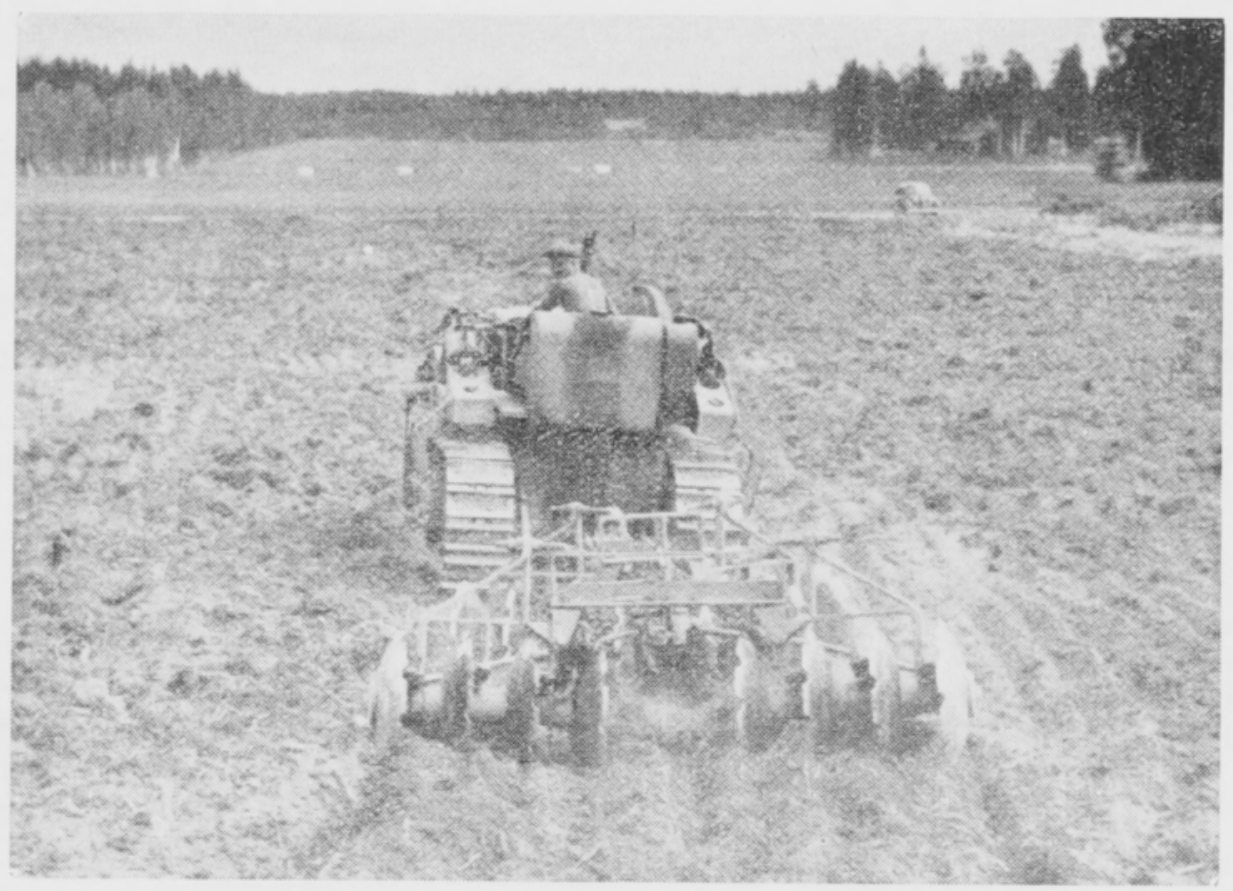

Fig. 7. Reclamation harrowing with a Rome Plow harrow. International $\mathrm{TD}_{14}$ track-type tractor used as draught machine.

Usually, reclamation harrowing is therefore carried out with heavy disc harrows, the diameter of the discs being about $60 \mathrm{~cm}$. Five-ton caterpillar-type tractors provide the draught power. The harrowing is mostly done at least twice. If the bog is "sinewy» or if there is peat in the surface layer that has not become muddy, it is generally advantageous to use disc harrows with toothed edges on the discs (Fig. 7). These harrows, which are heavier than ordinary disc harrows, generally require caterpillar-type tractors in the 9-ton class to supply the draught power. In some cases reclamation ploughing can be entirely replaced by the soil prepara tion accomplished by such harrowing, though, this can be done only under extremely favourable conditions and when the peat has throughout almost turned into mud.

According to statistics dating from 1953-1954, and covering a total of about 5800 effective working hours of reclamation harrowing, the average expenditure of labour was 3.6 effective working hours/ha., and the average mechanical operation costs $6100 \mathrm{Fmk}$./ha., with the harrowing being performed in general at least twice.

\section{Developing the Equipment and Methods}

Preliminary measures for the starting of mechanized clearing operations were taken in 1940, but owing to the war and the machine acquisitions the actual program was not initiated until 1946 .

The tractors of the caterpillar-type have always been bought abroad, mainly in the United States; and they have been mostly Caterpillar and Allis-Chalmers models. 
In recent years machines have, to some extent, also been imported from other countries, such as England, Italy and France.

At first all the other equipment, such as bulldozers, plows and harrows, were also purchased abroad, but soon it was realised that good results could be achieved only by developing equipment specially suited to conditions in Finland. Thus began a steady activity of research and experiment, which produced e.g. the stumpfork, the large land clearing plough, the open-ditch plough designed for land clearing drainage, and the forest ditching plough. Alongside the research work devoted to work equipment, operation methods have been developed and skilled labour trained.

The developing of equipment and methods has mostly been carried out in connection with practical operations and in the main on the initiative of the Pellonraivaus Oy. During the period 1945-1950, corresponding research was carried out by the Institute of Agricultural Economy of the University of Helsinki (Helsingin yliopiston maanviljelystaloudellinen laitos) and the Settlement Committee of the Central Federation of Agricultural Clubs (Maatalousseurojen Keskusliiton asutusvaliokunta) (4).

As pointed out in the beginning, the main part of Finland's reclaimable land is situated in the North, consisting of numerous uniform and extensive areas of wet peatland. These areas afford exceedingly good possibilities for mechanized land clearing operations, as well as, in general, for activities aimed at developing and guiding agriculture under the barren climatic conditions prevailing in the far North of Finland.

\section{REFERENCES}

(1) Hyppölä, J; Tunkelo, A. \& Törnqvist, L. 1949. Suomen väestöä, sen uusiutumista ja tulevaa kehitystä koskevia laskelmia. (Calculations relating to the population of Finland, its renewal and its future development). Tilastoll. tiedonant. (Statistical Communications) 38. Helsinki.

(2) Krvinen, E. 1948. Några undersökningar för utnyttjandet av myrarna i Finland. (Some studies relating to the exploitation of swamps in Finland). Medd. fra det norske myrselsk. (Communications of the Norwegian Bog Society) 46. Lillehammar.

(3) Maatilatalouden yhteisvaliokunnan uudisraivaustoimikunnan muistio (moniste) 1955. (Report of the land clearing commission of the joint farm economy board. Copy) Helsinki.

(4) Pinkala, R. 1951. Nyodling och olika metoder för denna. (Pioneer tillage and various methods of carrying it out). Nord. jordbr.forskn. (Nord. agricul. stud.) 4. Helsinki.

(5) Silvferberg, B. 1948. Uudisraivaus. (Land clearing). Työtehoseuran julk. (Public. of the Work Effic. Soc.) 48. Helsinki.

(6) VäISÄNEN, P. O. 1954. Uudisraivauksen tarpeellisuudesta. (On the necessity of land clearing). Asutustoiminnan aikak. (Periodical of Colonization Activity) 4. Vammala. 
SELOSTUS:

HAVAINTOJA SUOMAIDEN KONEELLISESTA UUDISRAIVAUKSESTA SUOMESSA

Kauko Maijala

\section{Pellonraivaus Oy, Helsinki}

Esityksessä on käsitelty niitä kokemuksia, joita Suomessa on vuosina 1945-1954 saatu koneiden käytöstä suomaiden uudisraivauksessa. Kirjoitukseen sisältyy Pellonraivaus Oy:n työmailta etupäässä vuosina 1950-1954 saatuun tilastoaineistoon perustuvia tietoja keskimääräisestä työnmenekistä ja keskihinnoista uudisraivauksen eri osatöissä.

B E R I C T I G U N G :

Im 27. Jahrgang (1955) der Zs. Maataloustieteellinen Aikakauskirja ist in dem Artikel, S. 229-233, "Lauri Saloheimo: Kalvakkanevan viljelysarvosta." Referat: "Über den Anbauwert von Sphagnum fuscum-Moor." im deutschen Referat S. 233 die Bezeichnung Sphagnum fuscum-Moor benutzt worden. Sie ist mit Sphagnum papillosum-Moor zu berichtigen. Derselbe Fehler erschien im Inhaltsverzeichnis des Jahrgangs der Zeitschrift und im Inhaltsverzeichnis seiner vierten Nummer.

\section{MAATALOUSTIETEELLINEN AIKAKAUSKIRJA}

\section{TOIMITUSKUNTA}

Ilmari Poijärvi
Päätoimittaja

Tikkurila. Puh. 831244 ja 831308

\author{
E. A. Jamalainen \\ Toimitussihteeri
}

Tikkurila. Puh. 831419 ja 831318

Erkki Kivinen, Antti Mäki, Vilho A. Pesola, Onni Pohjakallio, Orvo Ring

MAATALOUSTIETEELLISTA AIKAKAUSKIRJAA

ilmestyy 4 vihkoa vuodessa sisältäen kukin $2-4$ painoarkkia

Käsikirjoitukset lähetetään joko päätoimittajalle tai toimitussihteerille (os. Tikkus rila) tai jollekin toimitusvaliokunnan jäsenelle

SUOMEN MAATALOUSTIETEELLINEN SEURA

Puheenjohtaja :

Professori Martti Salonen

Tikkurila

Varapuheenjohtaja:

Professori Veikko Kanervo

Tikkurila
Sihteeri :

Professori V. Vainikainen Kasarmik. 38 A 8, Helsinki

Rahastonhoitaja :

Tohtori Orvo Ring

Tikkutila

Kirjastonhoitaja:

Maisteri Majlis Tulander, Hallituskatu 3, Helsinki 